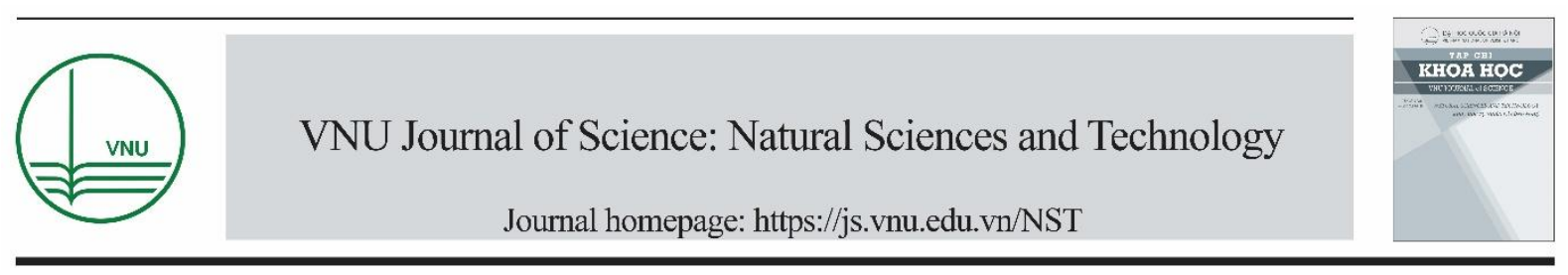

Original Article

\title{
Evaluating Formation and Bioactivity of New Sol-gel Bioactive Glass
}

\author{
Bui Xuan Vuong* \\ Faculty of Pedagogy in Natural Sciences, Sai Gon University, \\ 273 An Duong Vuong street, District 5, Ho Chi Minh City, Vietnam \\ Received 26 November 2018 \\ Revised 09 January 2019; Accepted 16 March 2019
}

\begin{abstract}
This paper discusses the synthesis of three ceramic compositions: $50 \mathrm{SiO}_{2-}$ $50 \mathrm{CaO}(\mathrm{A}), 45 \mathrm{SiO}_{2}-45 \mathrm{CaO}-10 \mathrm{P}_{2} \mathrm{O}_{5}(\mathrm{~B})$ and $40 \mathrm{SiO}_{2}-40 \mathrm{CaO}-20 \mathrm{P}_{2} \mathrm{O}_{5}(\mathrm{C})(\mathrm{wt} \%)$ using the sol-gel technique. XRD analysis demonstrates that only sample $\mathrm{C}$ can form bioactive glass material. Treated temperatures and heated times were also evaluated. The analysis data show that bioglass $40 \mathrm{SiO}_{2}-40 \mathrm{CaO}-20 \mathrm{P}_{2} \mathrm{O}_{5}(\mathrm{wt} \%)$ can successfully elaborate when the ceramic powder is heated at $750{ }^{\circ} \mathrm{C}$ for 3 hours. "In vitro" experiment was effectuated to investigate the bioactivity of bioglass $40 \mathrm{SiO} 2-40 \mathrm{CaO}-20 \mathrm{P}_{2} \mathrm{O}_{5}$ by soaking powder samples in SBF solution. The obtained result confirms the formation of hydroxyapatite (HA) phase on glass surface after 15 days of immersion, in which HA formation orients following (211) and (222) miller planes in crystalline structure of HA phase.
\end{abstract}

Keywords: Sol-gel, bioglass, hydroxyapatite, SBF, bioactivity.

\section{Introduction}

Bioactive glasses (Bioglasses) are materials which has the ability to repair and replace diseased or damaged bone [1,2]. When these materials are immersed in physiological medium, they interact with environment and

\footnotetext{
*Corresponding author.

Email address: buixuanvuongsgu@gmail.com
}

https://doi.org/10.25073/2588-1140/vnunst.4832 release calcium, phosphate ions. The gradual crystallization of calcium and phosphate ions results in the formation of an apatite layer which allows bone grafting [2-4]. The first bioglass in the quaternary system $\mathrm{SiO}_{2}-\mathrm{CaO}-$ $\mathrm{Na}_{2} \mathrm{O}-\mathrm{P}_{2} \mathrm{O}_{5}$ was synthesized by Larry Hench. This glass has been used since decades in many medical devices used for orthopedic and dental treatments [3-5]. Generally, bioglasses are elaborated by the traditional melting-quenching process which requires high temperatures and greatly limits the porosity and specific surface 
of biomaterials. Besides, this method has disadvantage of evaporation of volatile component during high temperature treatment $[6,7]$.

An alternative approach to prepare bioglasses without melting process is the sol-gel technique which operates at low temperature $[8,9]$. This way can elaborate a wide range of compositions with high purity, homogeneity and production of different shapes such as monoliths, powders, fibers or coatings [10]. Additionally, sol-gel synthetic glasses exhibit higher surface area and porosity which are important factors for their bioactivity [11].

Various research groups have applied the solgel technique for preparation of bioglasses in binary $\mathrm{SiO}_{2}-\mathrm{CaO}$, ternary $\mathrm{SiO}_{2}-\mathrm{CaO}-\mathrm{P}_{2} \mathrm{O}_{5}$ and quaternary $\mathrm{SiO}_{2}-\mathrm{CaO}-\mathrm{P}_{2} \mathrm{O}_{5}-\mathrm{MgO}$ systems for biomedical applications. "In vitro" studies have mentioned that nucleation and crystallization rates of biological hydroxyapatite (HA) depend on some factors including the glass composition. The study of Xia and Chang [12] has showed that the sizes of the sol-gel nano-bioglass particles were controlled in range of $20-40 \mathrm{~nm}$ by adjusting the concentrations of ammonia solution in an alkali-mediated sol-gel process. Li et al [13] studied the bioactivity of sol-gel derived quaternary bioglass system $\mathrm{SiO}_{2}-\mathrm{CaO}-\mathrm{P}_{2} \mathrm{O}_{5}-$ $\mathrm{Na}_{2} \mathrm{O}$, apatite layer has been identified when glass immersed in a TRIS buffer solution. Lao et al [14] synthesized gel-glass powders containing $75 \mathrm{wt} \% \mathrm{SiO}_{2}$ and $25 \mathrm{wt} \% \mathrm{CaO}$ using the sol-gel process. The obtained glass has been proved to be homogeneous and the Ca-P layer growth was easier since the phosphate ions coming from the solution. The bioactivity and biocompatibility of sol-gel glass composed of $\mathrm{SiO}_{2}-\mathrm{CaO}-\mathrm{P}_{2} \mathrm{O}_{5}-\mathrm{ZnO}$ have studied by Balamurugan et al [15]. The investigations shows that the incorporation of $\mathrm{Zn}$ into the bioglass system does not diminish the bioactivity of bioglass and the addition of $\mathrm{Zn}$ is beneficial for cell attachment and for maintaining the $\mathrm{pH}$ of SBF. The combination of sol-gel and co-precipitation processes was effectuated to synthesize nanoparticles of bioglass with sizes of $30-100 \mathrm{~nm}$ in diameter [16]. The synthetic bioglass could rapidly induce the carbonated hydroxyapatite from solution after 3 days of immersion. In addition, the bioactivity of bioglass is fully dependent on sintering temperature or crystallization temperature. The increase of sintering temperature has led to decrease the bioactivity and biocompatibility but improve the mechanical properties of glass samples. Similar observation was also recorded by Peitl et al [17] when studying the bioglass with chemical compositions of $1 \mathrm{Na}_{2} \mathrm{O}-2 \mathrm{CaO}-3 \mathrm{SiO}_{2}$ and $1.5 \mathrm{Na}_{2} \mathrm{O}-1.5 \mathrm{CaO}-3 \mathrm{SiO}_{2}$, containing different wt $\%$ of $\mathrm{P}_{2} \mathrm{O}_{5}$. Liu et al [18] studied the bioactivity, biodegradability and mechanical strength of sol-gel bioglass with composition of $58 \mathrm{~mol} \% \mathrm{SiO}_{2}, 38 \mathrm{~mol} \% \mathrm{CaO}$ and $4 \mathrm{~mol} \%$ $\mathrm{P}_{2} \mathrm{O}_{5}$. The bioglass powder was pressed and then sintered at 500, 800, 1000, and $1200{ }^{\circ} \mathrm{C}$, respectively. It was found that at sintering temperatures above $800^{\circ} \mathrm{C}$, the bioactivity and bio-degradability of the bioglass started to decrease.

The main objective of this work concerns the evaluation of some factors including glass composition and heating temperature to synthesize a new bioglass system by using the sol-gel technique. Three samples $50 \mathrm{SiO}_{2-}$ $50 \mathrm{CaO}, 45 \mathrm{SiO}_{2}-45 \mathrm{CaO}-10 \mathrm{P}_{2} \mathrm{O}_{5}$ and $40 \mathrm{SiO}_{2}-$ $40 \mathrm{CaO}-20 \mathrm{P}_{2} \mathrm{O}_{5}$ (wt\%) were selected for study. The suitable conditions for bioglass synthesis were evaluated and indicated. The bioactivity of optimal sol-gel bioglass was also evaluated via "in vitro" experiments.

\section{Materials and Method}

\subsection{Materials}

The main chemicals for elaborating sol-gel ceramics are listed as bellows:

Tetraethylorthosilicate (TEOS, $\mathrm{Si}\left(\mathrm{OC}_{2} \mathrm{H}_{5}\right)_{4}$, 99.999\%, Sigma-Aldrich), triethylphosphate (TEP, $\mathrm{OP}\left(\mathrm{OC}_{2} \mathrm{H}_{5}\right)_{3}, 99.8 \%$, Sigma-Aldrich), calcium nitrate tetrahydrate $\left(\mathrm{Ca}\left(\mathrm{NO}_{3}\right)_{2} \cdot 4 \mathrm{H}_{2} \mathrm{O}\right.$, 99\%, Sigma-Aldrich) and nitric acid $\left(\mathrm{HNO}_{3}\right.$, $70 \%$, Sigma-Aldrich). 


\subsection{Sol-gel synthesis}

The sol-gel synthesis of three compositions $50 \mathrm{SiO}_{2}-50 \mathrm{CaO}(\mathrm{A}), 45 \mathrm{SiO}_{2}-45 \mathrm{CaO}-10 \mathrm{P}_{2} \mathrm{O}_{5}(\mathrm{~B})$ and $40 \mathrm{SiO}_{2}-40 \mathrm{CaO}-20 \mathrm{P}_{2} \mathrm{O}_{5} \quad(\mathrm{C}) \quad(\mathrm{wt} \%)$ was briefly described following several steps. Firstly, TEOS and TEP were dissolved in distilled water. The solution of nitric acid $1 \mathrm{M}$ was added to hydrolyze the precursors. The reaction mixture was stirred for 60 minutes at the room temperature. Next, the amount of $\mathrm{Ca}\left(\mathrm{NO}_{3}\right)_{2} \cdot 4 \mathrm{H}_{2} \mathrm{O}$ was added slowly and continuously stirred with the same time as step 1 to result in a transparent sol. The condensed gel was completely formed in 5 days. Finally, the wet gel was dried at $60{ }^{\circ} \mathrm{C}$ for 1 day and then treated at $650,750,850$ and $950^{\circ} \mathrm{C}$ for 3 hours to obtain ceramic powders.

\subsection{In vitro experiments}

The "in vitro" tests were effectuated by immersing powder samples of the optimal bioglass in a container filled with the SBF solution (Simulated Body Fluid). The composition of SBF solution is similar to that of human blood plasma as presented in Table 1 . It was prepared according to the Kokubo's method [19]. The samples were immersed in the SBF solution for 1, 3, 6, 10 and 15 days and remained in an incubator at $37{ }^{\circ} \mathrm{C}$. The ratio of glass powder to solution volume of the SBF was $1 / 2(\mathrm{mg} / \mathrm{mL})$. After each period of soaking time, the samples were removed from the solution, gently rinsed with distilled water and dried at room temperature. The dried powders were stored to physic-chemical characterizations.

Tab. 1. Ionic concentrations ( $\mathrm{mM}$ ) of blood plasma and synthetic SBF

\begin{tabular}{llllllll}
\hline Ions & $\mathrm{Na}^{+}$ & $\mathrm{K}^{+}$ & $\mathrm{Ca}^{2+}$ & $\mathrm{Mg}^{2+}$ & $\mathrm{Cl}^{-}$ & $\mathrm{HCO}_{3}^{-}$ & $\mathrm{HPO}_{4}{ }^{2-}$ \\
\hline SBF & 142.0 & 5.0 & 2.5 & 1.5 & 148.8 & 4.2 & 1.0 \\
Plasma & 142.0 & 5.0 & 2.5 & 1.5 & 103.0 & 27.0 & 1.0 \\
\hline
\end{tabular}

\subsection{Physic-chemical characterizations}

The crystallinity of ceramic powders was evaluated by X-ray diffraction (XRD) with a Bruker D8 Advance diffractometer using a monochromatic copper radiation $(\mathrm{CuK} \alpha)$ of wavelength $\lambda=0.154 \mathrm{~nm}$. Powder samples were mixed homogeneously with cyclohexane and dropped on the surfaces of plastic tablets. Then, these tablets were dried to remove the solvent and introduced into diffractometer. The XRD data were acquired with a scanning speed of $1 \% \mathrm{~min}$. The crystalline phases were then identified by the powder diffraction files of the International Centre for Diffraction Data (ICDD) and scientific references. The XRD measurements were effectuated at Viet-Duc Technology Center, Ho Chi Minh City University of Food Industry. Scanning electron microscopy (SEM) was also used to evaluate the morphological surface of the optimal synthetic bioglass. The powder sample was metalized by coating gold-palladium layer to make it conductive before being put into analysis chamber. The surface observations of sample were carried out by collecting topographic contrast of secondary electrons. The micrographs of this work were performed on JEOL JSM 6301 microscope at Institute for Nanotechnology (INT), Vietnam National University - Ho Chi Minh City (VNUHCM).

\section{Results and discussion}

\subsection{Evaluation of glass formation}

XRD diagrams of three samples $50 \mathrm{SiO}_{2}-50 \mathrm{CaO}$ (A), $45 \mathrm{SiO}_{2}-45 \mathrm{CaO}-10 \mathrm{P}_{2} \mathrm{O}_{5}$ (B) and $40 \mathrm{SiO}_{2}-$ $40 \mathrm{CaO}-20 \mathrm{P}_{2} \mathrm{O}_{5}(\mathrm{C})$ heated at $650{ }^{\circ} \mathrm{C}$ for 3 hours are presented in figure 1. For the sample A, some characteristic peaks were identified at $30.8^{\circ}, 31.2^{\circ}, 32.8^{\circ}, 36^{\circ}, 38.1^{\circ}$ and $39.8^{\circ}(2 \theta)$. According to references [20-22], four peaks at $30.8^{\circ}, 31.2^{\circ}, 32.8^{\circ}$ and $39.8^{\circ}$ with miller planes (210), (120), (202) and (122) respectively, assigned to $\mathrm{Ca}_{2} \mathrm{SiO}_{4}$ phase. The peak at $36^{\circ}$ 
(412) is characteristic of $\mathrm{CaSiO}_{3}$ phase. The last peak at $38.1^{\circ}$ correspond to $\mathrm{Ca}\left(\mathrm{NO}_{3}\right)_{2}$ salt. The obtained result confirmed the existence of crystalline phases on the structure of synthetic ceramic. The presence of $\mathrm{Ca}\left(\mathrm{NO}_{3}\right)_{2}$ can be interpreted as being created by $\mathrm{Ca}\left(\mathrm{NO}_{3}\right)_{2} \cdot 4 \mathrm{H}_{2} \mathrm{O}$ hydration during heating process. Then, the $\mathrm{Ca}\left(\mathrm{NO}_{3}\right)_{2}$ component decompose to result in $\mathrm{CaO}$. The association of $\mathrm{CaO}$ and $\mathrm{SiO}_{2}$ formed $\mathrm{CaSiO}_{3}$ phase following the reaction $\mathrm{CaO}+$ $\mathrm{SiO}_{2} \rightarrow \mathrm{CaSiO}_{3}$. The formation of $\mathrm{Ca}_{2} \mathrm{SiO}_{4}$ phase is explained by the next reaction $\mathrm{CaO}+$ $\mathrm{CaSiO}_{3} \rightarrow \mathrm{Ca}_{2} \mathrm{SiO}_{4}$. When adding 10 percentages (wt \%) of $\mathrm{P}_{2} \mathrm{O}_{5}$ (Fig. 1B), XRD diagram expressed clearly the change of line shape. The double peaks at around $31^{\circ}$ seemed to be expanding. The other peaks at about $32.8^{\circ}$, $36^{\circ}, 38.1^{\circ}$ and $39.8^{\circ}$ decreased in intensity or disappeared. The double peaks at $31^{\circ}$ were disappeared and became a broad halo when the sample added with 20 percentage (wt \%) of $\mathrm{P}_{2} \mathrm{O}_{5}$ (sample $\mathrm{C}$ ). Other peaks were not found. Therefore, the increase in $\mathrm{P}$ content caused to a decrease in crystallization and led to the formation of amorphous state of synthetic ceramic as observed in XRD diagram of sample C.

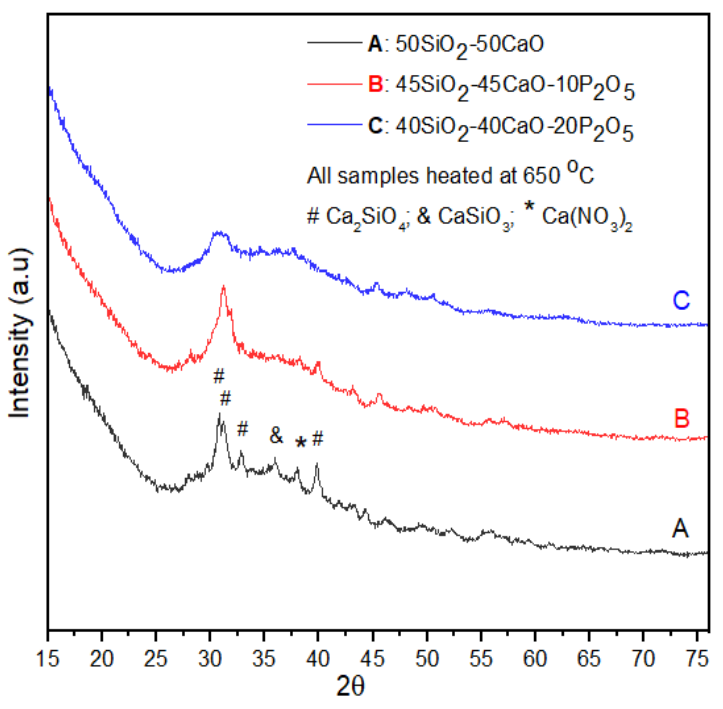

Fig. 1. XRD pattern of ceramic samples treated at $650^{\circ} \mathrm{C}$.

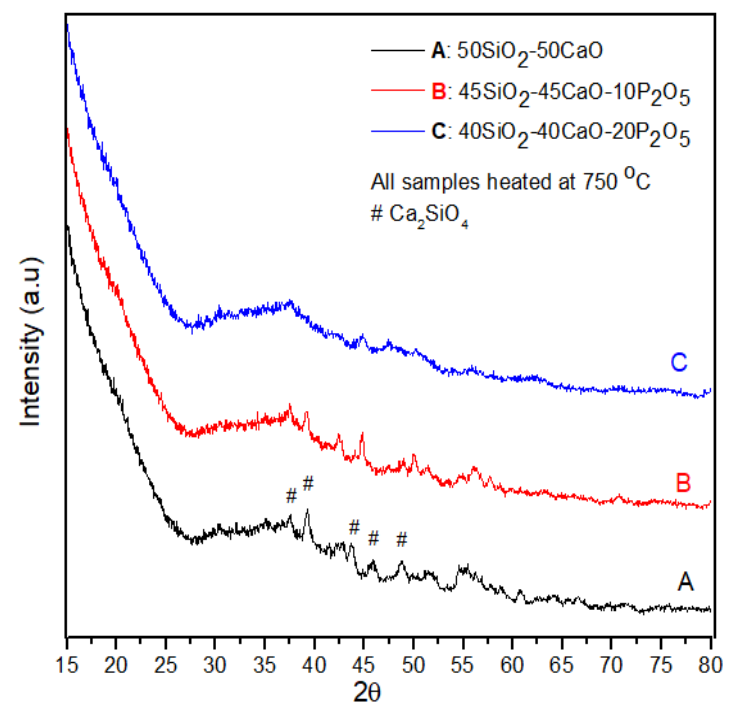

Fig. 2. XRD of ceramic samples treated at $750^{\circ} \mathrm{C}$.

Through reviewing scientific references [23], the $\mathrm{Si}$ and $\mathrm{P}$ elements are network formers existing in covalently bonds -O-Si-O-P- in the structure of glass while the $\mathrm{Ca}$ elements play a role as network modifiers present in ionic bonds -O-Si-O-Ca ${ }^{2+}-\mathrm{O}-\mathrm{P}-$. The increase of $\mathrm{P}$ (network formers) needs to use $\mathrm{Ca}^{2+}$ ions (network modifiers) to break down -O-Si-O-Si-O-P-O$\mathrm{Si}$ - bonds. This can stimulate the diffusion of $\mathrm{Ca}^{2+}$ ions to participate in ionic bonds as well as making $\mathrm{Ca}$ elements not redundant to use for other reactions.

Figure 2 presented the XRD diagrams of the samples heated at $750{ }^{\circ} \mathrm{C}$ for 3 hours. In the XRD diagram of sample $50 \mathrm{SiO}_{2}-50 \mathrm{CaO}(\mathrm{A})$, no peak at $31^{\circ}(2 \theta)$ could be found as observed in the sample heated at $650{ }^{\circ} \mathrm{C}$. The peaks of $\mathrm{Ca}\left(\mathrm{NO}_{3}\right)_{2}$ and $\mathrm{CaSiO}_{3}$ phases did not appeared. Some peaks with weak intensity were observed at $37.5^{\circ}, 39.3^{\circ}, 43.8^{\circ}, 46.3^{\circ}$ and $48.9^{\circ}(2 \theta)$. By studying previous literatures [20, 24], all of these peaks correspond to $\mathrm{Ca}_{2} \mathrm{SiO}_{4}$ phase with miller planes (002), (203), (114), (222) and (204) respectively. This result confirmed the effect of heating temperature on the formation of synthetic ceramic. Thus, the $\mathrm{Ca}\left(\mathrm{NO}_{3}\right)_{2}$ compound was used completely to decompose into $\mathrm{CaO}$ oxide at $750{ }^{\circ} \mathrm{C}$. Next, the reaction of 
$\mathrm{CaO}$ and $\mathrm{CaSiO}_{3}$ resulted in only $\mathrm{Ca}_{2} \mathrm{SiO}_{4}$ phase as shown in XRD diagram.

At the same heating condition, the sample B with $10 \mathrm{wt} \%$ of $\mathrm{P}_{2} \mathrm{O}_{5}$ expressed the similar peaks like the sample (A) but with lower intensities. Sample $\mathrm{C}$ with the addition of 20 wt $\%$ of $\mathrm{P}_{2} \mathrm{O}_{5}$ had not any crystalline peaks. This highlighted the amorphous state of the synthetic material which is characteristic of natural glassy state of bioglass.

\subsection{Optimal conditions to elaborate the sol-gel bioglass}

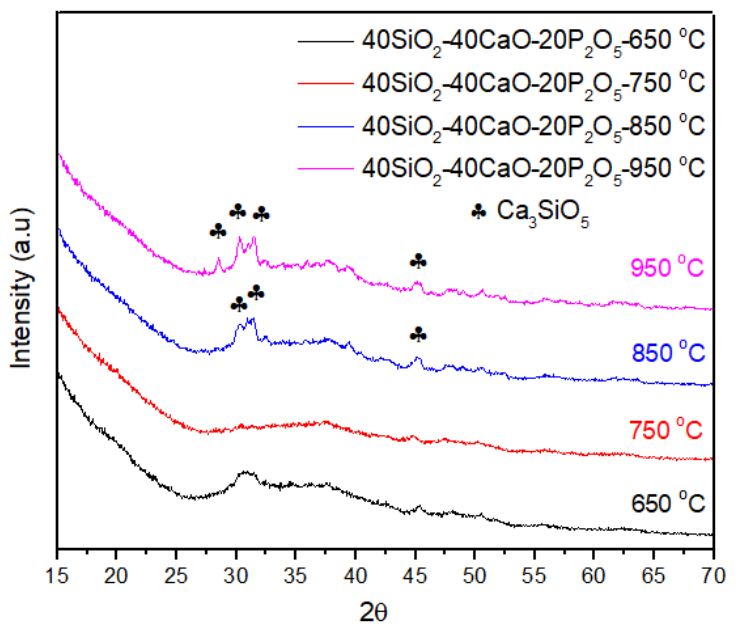

Fig. 3. XRD of bioglass $40 \mathrm{SiO}_{2}-40 \mathrm{CaO}-20 \mathrm{P}_{2} \mathrm{O}_{5}$ treated at different temperatures.

After heating three samples $50 \mathrm{SiO}_{2}-50 \mathrm{CaO}(\mathrm{A})$, $45 \mathrm{SiO}_{2}-45 \mathrm{CaO}-10 \mathrm{P}_{2} \mathrm{O}_{5}$ (B) and $40 \mathrm{SiO}_{2}-40 \mathrm{CaO}-$ $20 \mathrm{P}_{2} \mathrm{O}_{5}(\mathrm{C})$ at 650 and $750{ }^{\circ} \mathrm{C}$, the analyses by $\mathrm{XRD}$ highlighted that only sample $\mathrm{C}$ could form the amorphous state which is the natural characteristic of bioglass.

To select the suitable condition to synthesize the bioglass (C), the powder samples were heated at higher temperatures. Figure 3 presents the XRD diagrams of glass samples heated at different temperatures. It is recognized that the sample (C) expressed the perfect amorphous state when heated at $750{ }^{\circ} \mathrm{C}$ for 3 hours. The crystalline peaks appeared at $28.6^{\circ}, 30.5^{\circ}, 31.8^{\circ}$ and $45.3^{\circ}$ when the sample (C) heated at 850 and $950{ }^{\circ} \mathrm{C}$. These peaks correspond to miller planes (201), (009), (204) and (303) respectively in hexagonal system of $\mathrm{Ca}_{3} \mathrm{SiO}_{5}$ phase $[20,25]$. This confirmed the breaking of amorphous structure of bioglass to form the crystalline material. Summary, a new bioglass with the composition of $40 \mathrm{SiO}_{2}-40 \mathrm{CaO}-20 \mathrm{P}_{2} \mathrm{O}_{5}$ (C) has successfully elaborated by heating dried gel at $750{ }^{\circ} \mathrm{C}$ for 3 hours. This glass was served for further investigation in the next sections.

3.3. SEM observation of synthetic bioglass $40 \mathrm{SiO}_{2}-40 \mathrm{CaO}-2 \mathrm{OP}_{2} \mathrm{O}_{5}$

Figure 4 regrouped the images observed by SEM of bioglass at different magnifications. At the magnification of 500 times, the surface of biogalss seems to be smooth. The small particles were appeared on the bioglass surface at the magnification of 3000 times. These particles became more clearly at higher magnification as observing in the figure $4 \mathrm{C}$ and 4D.
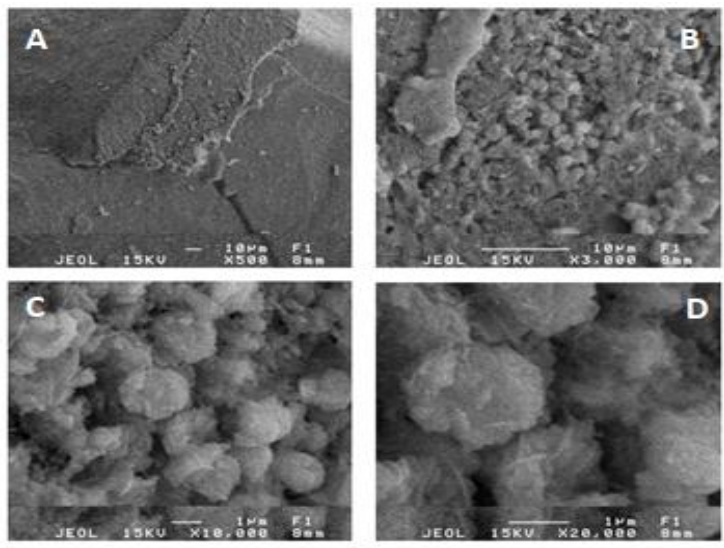

Fig. 4. SEM images of bioglass $40 \mathrm{SiO}_{2}-40 \mathrm{CaO}-$ $20 \mathrm{P}_{2} \mathrm{O}_{5}$.

\subsection{Evaluation of bioactivity of bioglass} $40 \mathrm{SiO}_{2}-40 \mathrm{CaO}-2 \mathrm{OP}_{2} \mathrm{O}_{5}(\mathrm{C})$

The bioactivity of bioglass $40 \mathrm{SiO}_{2}-40 \mathrm{CaO}-$ $20 \mathrm{P}_{2} \mathrm{O}_{5}$ was evaluated by soaking powder samples in the SBF solution. Figure 5 regroups the XRD diagrams of bioglass before and after "in vitro" experiments. The bioglass at 0 day (initial glass) did not express any crystalline peaks. This confirmed the amorphous property 
of synthetic material. After soaking in SBF, the samples appeared crystalline peaks as mentioned in the XRD diagrams. According to the references [1-4], the general active mechanism of bioglasses in SBF environment is summarized as follows:

(i) - Hydrolysis of silica groups in glass's structure by the interaction of bioglass and SBF solution

$$
\begin{aligned}
& -\mathrm{Si}-\mathrm{O}-\mathrm{Ca}^{2+}+\mathrm{H}^{+}+\mathrm{OH}^{-} \rightarrow-\mathrm{Si}-\mathrm{OH}+\mathrm{Ca}^{2+}(\mathrm{aq}) \\
& +\mathrm{OH}^{-}
\end{aligned}
$$

(ii) - Breaking of Si-O-Si bonds to form soluble silicic acid $\mathrm{Si}(\mathrm{OH})_{4}$

$\mathrm{Si}-\mathrm{O}-\mathrm{Si}+\mathrm{H}_{2} \mathrm{O} \rightarrow \mathrm{Si}(\mathrm{OH})_{4}$

(iii) - Condensation of silanols Si-OH of $\mathrm{Si}(\mathrm{OH})_{4}$ to form a silica gel layer

$-\mathrm{Si}-\mathrm{OH}+-\mathrm{Si}-\mathrm{OH} \rightarrow-\mathrm{Si}-\mathrm{O}-\mathrm{Si}-+\mathrm{H}_{2} \mathrm{O}$

(iv) - Migration of $\mathrm{Ca}^{2+}$ and $\mathrm{PO}_{4}{ }^{3-}$ from both the SBF solution and the glass sample to deposit an amorphous $\mathrm{CaO}-\mathrm{P}_{2} \mathrm{O}_{5}$ mixture on the silica gel layer

(v) - Crystallization of the amorphous CaO$\mathrm{P}_{2} \mathrm{O}_{5}$ film to form the crystalline biological hydroxyapatite (HA) layer. The HA material is similar to the inorganic component of natural bone.

For this new composition of bioglass $40 \mathrm{SiO}_{2-}$ $40 \mathrm{CaO}-20 \mathrm{P}_{2} \mathrm{O}_{5}$, the characteristic peaks of the $\mathrm{Ca}_{3}\left(\mathrm{PO}_{4}\right)_{2}$ phase was observed after 1 day of immersion. This is explained by the association of $\mathrm{Ca}^{2+}$ and $\mathrm{PO}_{4}{ }^{3-}$ following the reaction $3 \mathrm{Ca}^{2+}$ $+2 \mathrm{PO}_{4}{ }^{3-} \rightarrow \mathrm{Ca}_{3}\left(\mathrm{PO}_{4}\right)_{2}$. After 3 days of experiment, the peaks of $\mathrm{Ca}_{3}\left(\mathrm{PO}_{4}\right)_{2}$ were slightly shifted to the left side. This observation confirms the unstability of $\mathrm{Ca}_{3}\left(\mathrm{PO}_{4}\right)_{2}$ phase. Within a period of 6 to 10 days, the mineral $\mathrm{Ca}_{3}\left(\mathrm{PO}_{4}\right)_{2}$ was recorded as stable for a period of 6 to 10 days. The characteristic peaks were identified at $28.3^{\circ}(006), 30.7^{\circ}(105), 44.5^{\circ}(2-$ 16) and $55.5^{\circ}(2-19)$. When the soaking time increased to 15 days, the above characteristic peaks were moved to the right side. The new positions of characteristic peaks were identified to HA phase. In detail, two main HA peaks were observed at around 32 and $45^{\circ}(2 \theta)$ which corresponds to (211) and (222) miller planes. This confirmed the bioactivity of bioglass after "in vitro" experiment. This obtained result is according to previous studies where the $\mathrm{Ca}_{3}\left(\mathrm{PO}_{4}\right)_{2}$ material has been proved to be bioactive [2]. When soaked in SBF solution, this material is dissolved and then resulting ions precipitate into a new HA layer following the reaction $10 \mathrm{Ca}^{2+}+6 \mathrm{PO}_{4}^{3-}+2 \mathrm{OH}^{-} \rightarrow$ $\mathrm{Ca}_{10}\left(\mathrm{PO}_{4}\right)_{6}(\mathrm{OH})_{2}$. In the study of Larry Hench, the bioglass $45 \mathrm{~S}$ with composition of $\mathrm{SiO}_{2}(45$ wt \%), $\mathrm{Na}_{2} \mathrm{O}$ (24.5 wt \%), $\mathrm{CaO}(24.5 \mathrm{wt} \%)$ and $\mathrm{P}_{2} \mathrm{O}_{5}$ (6 wt \%) exhibited two HA principal peaks at $26^{\circ}(002)$ and $32^{\circ}(211)$ after "in vitro" test [2-3]. The new synthetic bioglass of this work expressed the different comportment of bioactivity compared to Larry Hench's glass. So, it can be considered that the formation of HA phase oriented at $32^{\circ}$ and $45^{\circ}$ peaks is due to the shifting of characteristic peaks of $\mathrm{Ca}_{3}\left(\mathrm{PO}_{4}\right)_{2}$ component during its dissolution in SBF fluid.

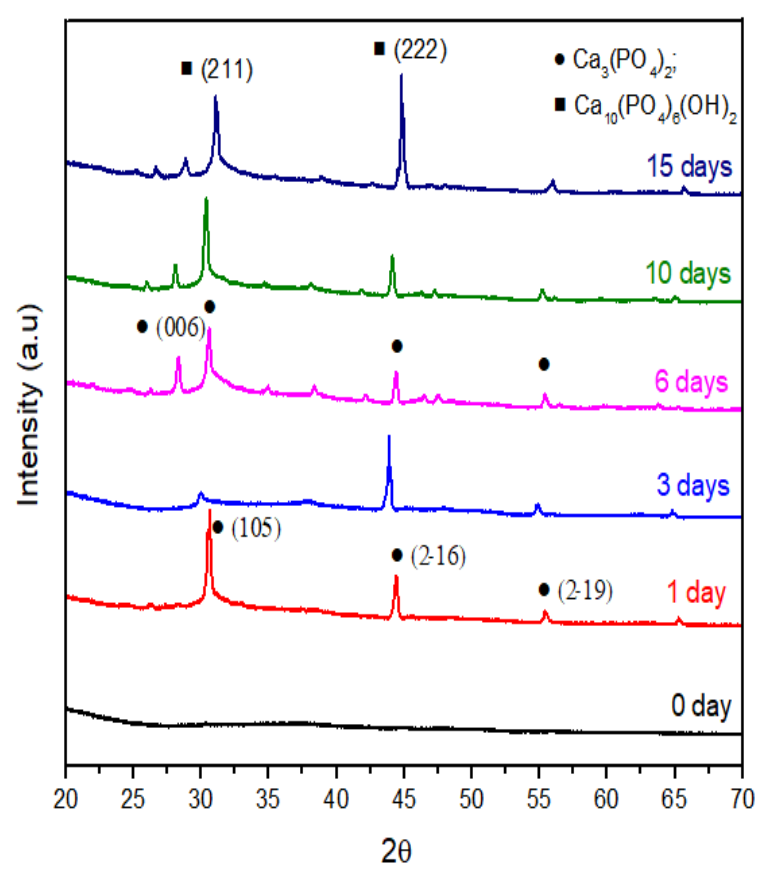

Fig.5. XRD diagrams of bioglass $40 \mathrm{SiO}_{2}-40 \mathrm{CaO}-$ $20 \mathrm{P}_{2} \mathrm{O}_{5}$ at different times in SBF. 


\section{Conclusion}

The XRD analyses of three sol-gel ceramic compositions $50 \mathrm{SiO}_{2}-50 \mathrm{CaO} \quad(\mathrm{A}), \quad 45 \mathrm{SiO}_{2}-$ $45 \mathrm{CaO}-10 \mathrm{P}_{2} \mathrm{O}_{5}(\mathrm{~B})$ and $40 \mathrm{SiO}_{2}-40 \mathrm{CaO}-20 \mathrm{P}_{2} \mathrm{O}_{5}$ (C) (wt\%) highlight that only the sample (C) with the composition of $40 \mathrm{SiO}_{2}-40 \mathrm{CaO}-20 \mathrm{P}_{2} \mathrm{O}_{5}$ can be form the sol-gel bioglass. The heating temperature was selected and optimized at 750 ${ }^{\circ} \mathrm{C}$ during 3 hours. The glassy state of bioglass $\mathrm{C}$ is disappeared by the appearance of crystalline peaks assigned to $\mathrm{Ca}_{3} \mathrm{SiO}_{5}$ phase when the bioglass heated at 850 and $950{ }^{\circ} \mathrm{C}$. The "in vitro" experiments confirm the bioactivity of glass $\mathrm{C}$ by forming the characteristic peaks oriented at different positions $\left(32^{\circ}\right.$ and $\left.45^{\circ}\right)$ in the hydroxyapatite crystalline structure.

\section{Acknowledgments}

This research was funded by Sai Gon University, Vietnam with the contract code 830/HĐ-ĐHSG.

\section{References}

[1] D.F. Williams, Definitions in Biomaterials, Consensus Conference for the European Society for Biomaterials, Chester, UK, 1986, Chapter 4. https://doi.org/10.1002/pol.1988.140260910

[2] L.L. Hench, Bioceramics: From Concept to Clinic, J. Am. Ceram. Soc. 74 (1991) 1487-1510. https://doi.org/10.1111/j.1151 2916.1991.tb07132.x

[3] L.L. Hench, The story of Bioglass, J. Mater. Sci. Mater. Med. 17 (2006) 967-978. https://10.0.3.239/s10856-006-0432-z

[4] X.V. Bui, H. Oudadesse, Y. Le Gal, A. Mostafa, P.Pellen and G. Cathelineau, Chemical Reactivity of Biocomposite Glass-Zoledronate, J. Aust. Ceram. Soc. 46 (2010) 24-28. https://www. austceram.com/volume-46-number-2-2010.

[5] L.L. Hench, Genetic design of bioactive glass, J. Euro. Ceram. Soc. 29 (2009) 1257-1265. https://doi.org/10.1016/j.jeurceramsoc.2008.08.002

[6] S. Kumar, P. Vinatier, A. Levasseur, K.J. Rao, Investigations of structure and transport in lithium and silver borophosphate glasses, J. Sol. Stat. Chem. 177 (2004)1723-1737. https://doi.org/10.1016/j.jssc.2003.12.034

[7] Z. Hong, A. Liu, L. Chen, X. Chen, X. Jing, Preparation of bioactive glass ceramic nanoparticles by combination of solgel and coprecipitation method, J. Non-Crys. Sol. 355 (2009) 368-372. https://doi.org/10.1016/j.jnoncrysol.2008.12.003

[8] D.B. Joroch, D.C. Clupper, Modulation of zinc release from bioactive sol-gel derived $\mathrm{SiO}_{2}-\mathrm{CaO}-\mathrm{ZnO}$ glasses and ceramics, J. Biomed. Mater. Res. Part A. 82A (2007) 575-588. https://doi.org/10.1002/jbm.a.31180

[9] J. Roman, S. Padilla, M. Vallet-Regi, Sol-Gel Glasses as Precursors of Bioactive Glass Ceramics, Chem. Mater. 15 (2003) 798-806. https:// 10.1021/cm021325c

[10] J. Lao, J.M. Nedelec, Ph. Moretto, E. Jallot, Biological activity of a SiO2-CaO-P2O5 sol-gel glass highlighted by PIXE-RBS methods, Nuc. Ins. Meth. Phys. Res. Sec. B. 245 (2006) 488-493. https://doi.org/10.1016/j.nimb.2007.03.092

[11] M. Vallet-Regi, L. Ruiz-Gonzalez, I. Izquierdo, J.M. Gonzalez-Calbet, Revisiting silica based ordered mesoporous materials: medical applications, J. Mater. Chem. 16 (2006) 26-31. https:// 10.1039/B509744D

[12] W. Xia, J. Chang, Preparation and characterization of nano-bioactive-glasses (NBG) by a quick alkali-mediated sol-gel method, Mater. Lett. 61 (2007) 3251-3253. https://doi.org/10.1016/j.matlet.2006.11.048

[13] R. Li, A.E. Clark, L.L. Hench, An investigation of Bioactive Glass Powders by Sol-Gel Processing, Trans. Ann. Meet. Soc. Biomater. 12 (1990) 231239. https://doi.org/10.1002/jab.770020403

[14] J. Lao, J.M. Nedelec, P. Moretto, E. Jallot, Imaging physicochemical reactions occurring at the pore surface in binary bioactive glass foams by micro ion beam analysis, App. Mater. Inter. 6 (2010) 1737-1742. https://10.1021/am1002316

[15] A. Balamurugan, G. Balossier, S. Kannan, J. Michel, A.H.S. Rebelo, J.M.F. Ferreira, Development and in vitro characterization of solgel derived $\mathrm{CaO}-\mathrm{P}_{2} \mathrm{O}_{5}-\mathrm{SiO}_{2}-\mathrm{ZnO}$ bioglass, Act. Biomater. 3 (2007) 255-262. https:// 10.1016/j.actbio.2006.09.005

[16] Z. Hong, A. Liu, L. Chen, X. Chen, X. Jing, Bioactive glass prepared by sol-gel emulsion, J. Non-Crys. Sol. 355 (2009) 119-123. 
https://doi.org/10.1016/j.jnoncrysol.2012.10.025

[17] O. Peital, E.D. Zanotto, L.L. Hench, Highly bioactive $\mathrm{P}_{2} \mathrm{O}_{5}-\mathrm{Na}_{2} \mathrm{O}-\mathrm{CaO}-\mathrm{SiO}_{2}$ glass-ceramics, $\mathrm{J}$. Non-Crys. Sol. 292 (2001) 115-126. https://doi.org/10.1016/S0022-3093(01)00822-5

[18] J. Liu, X. Miao, Sol-gel derived bioglass as a coating material for porous alumina scaffolds, Ceram. Inter. 30 (2004) 1781-1785.

https://doi.org/10.1016/j.ceramint.2003.12.120

[19] T. Kokubo, H. Takadama, How useful is SBF in predicting in vivo bone bioactivity, Biomater. 27 (2006) 2907-2915. https://10.1016/j.biomaterials.2006.01.017

[20] M. Dziadek, B. Zagrajczuk, P. Jelen, Z. Olejniczak, K.C. Kowalska, Structural variations of bioactive glasses obtained by different synthesis routes, Ceram. Inter. 42 (2016) 1470014709. https://doi.org/10.1016/j.ceramint.2016.06.095

[21] R. Lakshmi, V. Velmurugan and S. Sasikumar, Preparation and Phase Evolution of Wollastonite by Sol-Gel Combustion Method Using Sucrose as the Fuel, Combust. Sci. Tech. 185 (2013) 1777-1785. https://doi.org/10.1155/2018/6213568

[22] G. Voicu, A. Bădănoiu, E. Andronescu1, C. M. Chifiruc, Synthesis, characterization and bioevaluation of partially stabilized cements for medical applications, Cen. Euro. J. Chem. 11 (2013) 1657-1667. https://10.2478/s11532-013-0297-1

[23] M.V. Regi, Ceramics for medical applications, J. Chem. Soc. Dal. Trans. 2 (2001) 97-108. https://10.1039/B007852M

[24] G. Voicu, A.I. Bădănoiu, E. Andronescu, C.M. Chifiruc, Synthesis, characterization and bioevaluation of partially stabilized cements for medical applications, Cen. Euro. J. Chem. 11 (2013) 1657-1667. https://10.2478/s11532-013-0297-1

[25] M. Wu, T. Wang, Y. Wang, F. Li, M. Zhou, X. $\mathrm{Wu}, \mathrm{A}$ novel and facile route for synthesis of fine tricalcium silicate powders, Mater. Lett. 227 (2018), 187-190.

https://doi.org/10.1016/j.matlet.2018.05.029 